\title{
The Implementation of International Financial Reporting Standards (IFRS) in Libya: Difficulties, problems and challenges facing the Libyan companies working on the implementation of IFRS
}

\author{
Reda M. Elhouderi ${ }^{1}$
}

\begin{abstract}
The research aim of this paper is to provide a comprehensive understanding of the process of implementation of International Financial Reporting Standards (IFRS) in Libyan enterprises, by evaluating the current situation and giving examples of best practices in financial presentation and disclosure, which in turn could be used as a clear and efficient and effective guidance to help Libyan regulatory bodies and Libyan government continue with the on-going accounting and financial reporting reforms in the future.
\end{abstract}

Keywords: audit / financial reporting / reporting standards

\section{Introduction}

One of the most fundamental changes to affect financial reporting in recent times all around the World and in Libya has been the introduction of International Financial Reporting Standards (IFRS). Cairns (2004) describes these as:

"The term "IFRS" encompasses both IFRS issued by the IASB and international accounting standards (IAS) issued by the IASC and adopted or revised by the IASB."

For decades, many studies have looked into the importance of corporate entities' financial reporting and disclosure. Particular attention has been paid to differences in financial reporting practices of companies in different countries (which resulted in great complications for those preparing, consolidating, auditing and interpreting published financial statements).

${ }^{1}$ B.A. (Buss. Admin./Acc.), M.A. (Econ./Acc.), PhD Student at the University Business Academia, Novi Sad, Vojvodina, Serbia, redaelhouderi@hotmail.com 
Alexander and Christopher, (2001), argued rightly that since the preparation of internal information often overlaps with the preparation of published information, the complications spread further, and in order to overcome such issues, several organizations in the accounting and auditing profession throughout the world have been involved in attempts to further harmonise or standardize accounting.

Academic evidence agreed that harmonisation is needed to bring harmony and uniformity and eliminate discrepancies in the national practices of financial reporting. Pierce and Weetman, (2000), stated that harmonisation will be achieved when there is convergence of opinion on the way in which a specific item should be accounted for. It is the increase in comparability brought about when more companies adopt some accounting methods for an item and increases the frequency of accounting policy choices across countries.

By the end of the twentieth century, international influence and interest of the powerful corporate lobby groups had begun to affect accounting in all countries, sometimes overwhelmingly. The globalisation of the market had led to an increase in the need for internationally comparable and substantially standardized accounting information. Where several large multinational companies are based in comparatively small countries, international influences are likely to be great. For example, International Accounting Standard 1 (IAS1) requires that financial statements described as complying with International Accounting Standards should comply with all requirements of all the IAS. If national rules require compliance with IAS, then domestic mechanism can cover their enforcement. However, if IASs are merely allowed as an alternative or as a supplement to national rules, then there may be regulatory difficulties.

In Europe, since 2000 all listed companies have been required to use IASs for their consolidated financial statement (Alexander and Christopher, 2001). From 2005 onwards, Continental European countries that are members of the EU applied IAS instead of, or at the same time as, national rules. After all, it is important to realise that international accounting harmonisation, like many important global issues, is necessary as it helps to remove economic barriers within the European Union and in the highly globalized world economy and markets around the Globe, and also reduces obstacles to international investment and saves time and money for firms consolidating different financial information.

With the increase in business ties to developed countries, developing countries are getting involved in the same phenomenon of adopting international financial standards (IFRS). Nevertheless, there is a problem with the suitability and process 
of implementation of those standards in developing countries. Therefore, the assessment of whether harmonisation of accounting practices is feasible or not across the globe is absolutely essential.

\section{Assessment of the Need for Future Research in the IFRS Implementation in Libya}

(i.) To date, much of the discussion surrounding the introduction of IFRS at the national, regional and global level, in both academic and financial publications, has been based on:

(ii.) simulations of what might happen to company financial statements (Kasanen et al., 1992; Teodori and Veneziani, 2005);

(iii.) unreliable evidence from the experiences of early adopters (Accountancy Age, 2004; Financial Times, 2005);

(iv.) consultancy reports by firms advising companies on preparation for the change (KPMG Ireland, 2003; PriceWaterhouse Coopers, 2004);

(v.) empirical surveys of the practices or experiences of early adopters (Larson and Street, 2004; Ortiz, 2005); and

(vi.) the empirical findings of studies prior to the adoption of IFRS looking at the possible changes that might take place (Fearnley et al., 2007).

Preliminary evidence had suggested that changes to the financial statements and the whole process of financial reporting may be substantial. Therefore, the need for such research has emerged even more especially after the recent changes witnessed in Libya in order to preserve its seat and the national economic interests within the international community. In the continuation of this paper, we shall give more emphasis and a focus on the Libyan accounting background, environment, institutions and professional practice.

\section{Analysis of the Accounting System In Libya}

Libya,as many other countries has witnessed periods of colonization by multiple countries. It was under the Turkish leadership from the mid-16th century to 1911. Then it was an Italian colony from 1912 to 1943, and jointly managed by Britain and France from 1943 to 1951. 
With such dramatic history, Libyan systems have inheritance from colonial systems and social values of foreigners. The accounting system in Libya is not exempt of that inheritance and burden as well. The current accounting system in Libya is a mixture of different systems from different backgrounds. (Almabrouk, 2005)

In spite of this, Libya has witnessed vital changes in its business environment; accounting systems have not been given particular attention by policy makers in Libya. There is no obvious effort to adapt the colonial public administration systems and business regulation and organization or to develop Libyan own accounting system and standards which would be adapted to current needs and development of the country.

In fact, the accounting system in Libya was not a result of the needs of the local social and economic environment. Rather than that, it was totally imported from developed countries, for example, the United Kingdom, and there are no real changes or improvements reflecting the needs of the local Libyan environment in these systems.

Further, Bait EI-Mal et al. 1973; Kilani, 1988 argue that, the current Libyan system had been influenced partly by both the British and the American systems that are dedicated to serving the external users through financial reporting. However, the focus on the external financial reporting due to law requirements let companies disclose as little as possible, being focused on the user's needs in terms of reliable and useful information. Companies in Libya are required to present only the annual balance sheet and the loss and profit accounts according to the law, and most companies do not do more than that, which is logical behaviour and response on the low level of accounting and auditing regulation.

So far, in Libya there are no known accounting principles or accounting standards (Kilani, 1988), as there is no clear law which regulates the accounting profession. The only ethical requirements are caused by the tax law and the trade law, where the focus is on limited information only, and since these laws have not adopted any standards, their value is very limited in terms of guidance for accountants. As a result, the choice of most adequate accounting standards to be used has been left to personal views, preferences and interests of the accountants, auditors and company's managers.

The absence of a general regulatory framework of the Libyan accounting system, gives managers and accountants the chance to choose freely between different standards and accounting ways without having any accountability, whether what they have used is suitable or not. Thus, many managers and accountants misuse this 
ability for their personal interests. In addition to this absence, accounting systems applied vary among Libyan companies depending on the education background or the accountants or manager's needs.

Professional accounting in Libya seems to be in its early stages, and its effect on developing the accounting system is limited. In 1973, the first law was announced to control and organize accounting in Libya. This law stated on the establishment of the Accountants and Auditors Association, and that was the first and last step so far toward improving the system (El-Sherif. 1978).

However, since its establishment the association of accountants has not played any tangible role in improving accounting in Libya. Though professional accounting in Libya has kept a lot of the Anglo-Saxon system and approach, it has not gone far enough to improve the quality of accounting and auditing standards which should be adopted by professional accountants in Libya, by either making their own domestic standards or adopting international standards.

Therefore, the output of the Libyan accounting system is not as reliable as it should be, due to the difficulties in testing the quality of financial reports, which make the value of accounting information rather low and not fully comparable.

As a result we see that the Libyan accounting system suffers from many issues in terms of its financial reporting such as:

(i.) Inconsistency in preparing financial statements among entities, even those within the same professional area, e.g. banking industry.

(ii.) Due to the absence of specialized independent accounting organizations which regulate, control and guide the process of preparing unified financial statements, hence, each entity uses its own way to prepare these statements.

In 2006, the Libyan Government established a stock exchange market "Libya Stock Exchange" and as a result, the need for unified financial reporting standards was vital. Hence, the Libyan stock market regulations require the use of IFRSs for all the listed companies and the Libyan Banking Law requires the use of IFRSs for all commercial banks.

With the current need to adopt the IFRS in Libya, there is a high level of complexity and a lower level of understandability of how this can be possible or the implication on the accounts and financial statements. Therefore, perspective research in this area should focus on: 
(i.) Examine to what extent these requirements have been complied within Libya.

(ii.) Content analysis of financial statements of the Libyan listed companies and banks;

(iii.) an analysis of the reconciliation statement;

(iv.) investigate multiple stakeholder perspective and interests on the adoption of IFRS (including the preparers' perspective on the adoption of IFRS);

Based on the previous we could conclude that the main objectives of research of IFRS adoption in Libya should be:

a) Whether the information required under the new IFRS is thought to be useful for stakeholders?

b) Measure the nature and extent of the changes in financial reporting that have been experienced as a result of IFRS adoption.

In the following analytical presentation it is obvious that Libya belongs to the third group of countries which pursue convergence with IFRSs, but with no plan to adopt and further develop the IFRS at the national level.

Presentation 1: Global Spread of the IFRS

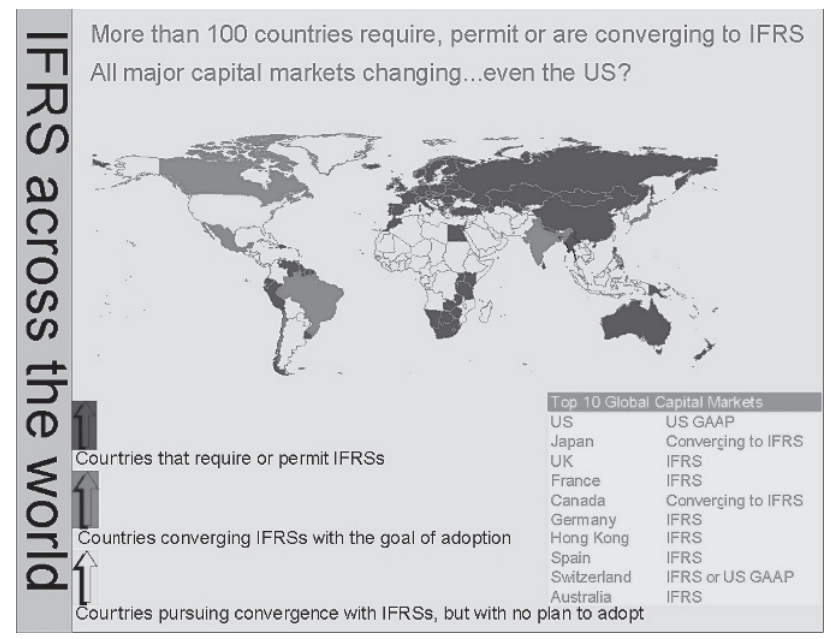

Source: Price Waterhouse Coopers, LLP; web-page visited on 08/18/2014 


\section{Analysis of the Turn-Between the Business Decision Process and Usefulness of the Accounting Information in Libya}

The starting point in analysis is to define a broader theoretical framework of contemporary research related to the role and level of usefulness of the accounting information for the corporate decision making process and for the government and accounting profession regulation in Libya. In September 1989, the IASC published its Framework for the Preparation and Presentation of Financial Statements. This document was largely based on the equivalent document issued by the FASB in the US. However, it was not issued as an accounting standard and therefore does not override individual IFRS. The IASC's framework was divided into seven major sections:

(i.) The objectives of financial statements.

(ii.) Underlying assumptions.

(iii.) Qualitative characteristics of financial statements.

(iv.) The elements of financial statements.

(v.) Recognition of elements of financial statements.

(vi.) Measurement of elements of financial statements.

(vii.) Concepts of capital maintenance.

In the first section the framework stated that the objective of financial statements was:

"[T]o provide information about the financial position, performance and changes in financial position of an enterprise that is useful to a wide range of users in making economic decisions." (IASC, 1989, paragraphs 22 and 23).

It then discusses why users need to know as an information base about:

(i.) Profitability.

(ii.) Financial position.

(iii.) Financial adaptability

(iv.) Cash generation. 
Similar discussions can be found in the frameworks of both the FASB and the UK's Accounting Standards Board (ASB)'s Statement of Principles. Decision-usefulness relationship and feedback, therefore, provides a logical approach for the current scientific research since it allows the researchers to evaluate objectively the financial statements produced under IFRS against an objective that the standardsetting body has itself proposed.

The following Presentation 2 is the obvious evidence of how strongly profound and sound accounting reform of the IFRS adoption at the national level is influencing the set of the profitability performance indicators on different sectors in Ghana. Probably, even better performance improvement could be forecasted in Libya since the national economy is more developed and much stronger. That is probably the main rationale to adopt IFRS and related regulatory changes on a broad scale in Libya, at the same foot with profound institutional building and social and economic reforms.

Presentation 2. The Influence of the Accounting Reform, e.g. IFRS Adoption on the Corporate Profitability

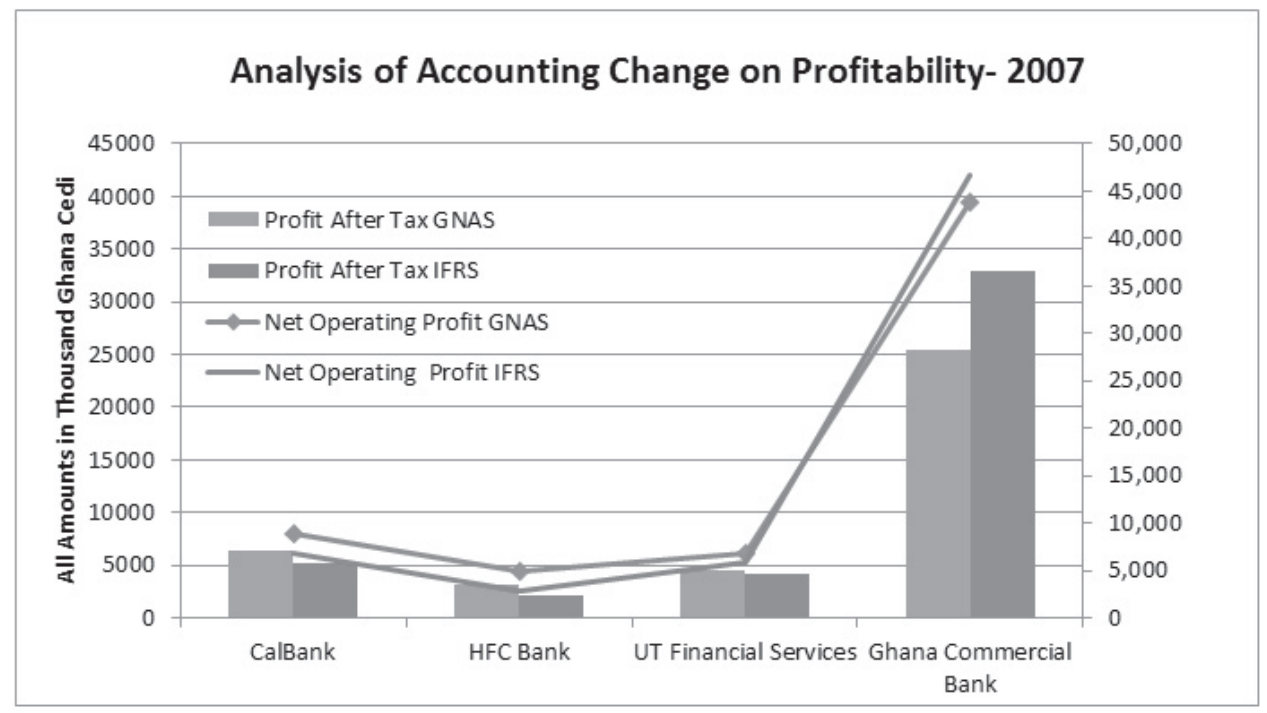

Source: Blog of Solomon Zori; IFRS in the African Continent: A look at Ghana; web-site visited on 08/19/2014 


\section{Perspectives and Futures Research Avenues on the Adoption of the IFRS in Libya}

Introduction and adoption of the IFRS financial statements in Libya are gradually bringing the best practices and presentation and disclosure methodology which in turn give relevant and useful public disclosure and presentation framework. This invaluable new and also revolutionary approach in accounting and financial reporting in Libya shall procedure the excellent disclosure and presentation ground that in turn shall be very beneficial for the discussion on the future steps in accounting reform in Libya by adoption of the IFRS and other related sets of standards.

Drawing from the planned carefully selected pool of Libyan companies in the research sample across various industries, but with some stress on oil and gas extraction, it is necessary to cover in future research the following areas:

(i.) How the framework of financial reporting based on the IFRS platform is functioning in practice.

(ii.) What are the practical obstacles and problems?

(iii.) It shall be covered virtually every required disclosure aspect.

The previous focal points in turn shall give to research a straightforward and precise picture of the financial reporting practice of the corporate sector in Libya.

\section{Perspectives on the IFRS Adoption and Comprehensive Accounting Reform in Libya}

The primary goal of IFRS adoption and comprehensive accounting reform in Libya should be based on the research which shall comprehensively cover all the disclosure process and aspects based on the IFRS framework, but in the Libyan legal and cultural environment not only at present, but bearing in mind the development and needs in the future.

The main goal of this research is to give examples of the best practice in financial presentation and disclosure, which in turn could be used as a clear and efficient and effective guidance to help Libyan companies in their financial reporting, but also to the regulatory body and Libyan government in terms of how to go on with the ongoing accounting and financial reporting reforms in future. Also, this paper should cover the aspects of current financial reporting practice by the Libyan enterprises vis-à-vis IFRS in order to speed up the accounting reform process and im- 
prove the results of this reform in terms of disclosure transparency and inevitable standardization. The financial reporting and accounting reforms in Libya based on the process of adoption of the IFRS shall observe the process of economic recovery and increasing foreign trade ties with the main trade partners countries of Libya, especially in the region, but also worldwide. At the same time, the goal is not only to conduct research and find reliable evidence on the IFRS adoption process, but also on the very complex and costly implementation and reaping the benefits of the international financial reporting standards in Libya. The future study shall explore the difficulties, problems and challenges facing the Libyan companies working on the implementation of the IFRS.

\section{Concluding Remarks}

Accounting regulation in Libya is extensively fragmented and not up to date, and consequently it does not fulfil its main purpose to minimise the remoteness gap created by the separation of management and ownership. In contemporary global economy IFRS dominates over accounting and financial reporting regulation on a global scale. For the Libyan financial reporting entities preparation of financial reports in accordance with IFRS could be a decisive factor in attracting foreign investments but also it could facilitate and increase the Libyan foreign direct investments abroad. The first significant U-turn in Libyan economy took place in the early 1990s as the government changed the economic framework by adopting open market economic policy as a new policy orientation, which also served as a reformist base for the national accounting system. That drastic and profound change has opened doors for foreign direct investments and allowed international companies to invest freely in Libyan market. That change presented a significant stimulus for further accounting reform in the country. In such orientation Libyan government enacted new laws which regulated the important banking sector as well as stock market operations. This regulatory reform in fact was not properly implemented, and stopped at the starting point just with the regulatory changes which unfortunately did not make a profound reform changes in the Libyan accounting and financial reporting system. The practical challenges and complexities of the profound and well-structured and prepared implementation of the IAS/IFRS in Libya are in front of us, without a clear time frame of the realization process in practice step by step. Our findings are in favour to implement in the first introductory step IFRS to Libyan listed corporations, and then in the second phase based on the knowledge and experience that shall be acquired in that process to spread the legal obligatory implementation that all other companies prepare financial re- 
ports based on the full implementation disclosure of the IAS/IFRS. Based on our preliminary findings, there has been no extensive scientific research on the accounting reforms and IFRS implementation in Libya, which consequently leads to a need and necessity of such approach. New academic curriculums in accountancy and auditing should be adopted and implemented in Libya, professional trainings of accountants and auditors should be improved and it is also necessary to make adequate investments in human resources in the prolonged period of a few decades, while at the same time a strong corporate governance reform should be adopted and implemented.

\title{
Primena Međunarodnih standarda finansijskog izveštavanja u Libiji: teškoće, problem i izazovi sa kojima se suočavaju libijske kompanije u procesu implementacije Međunarodnih računovodstvenih standarda
}

\author{
Reda M. Elhouderi
}

\begin{abstract}
Sažetak: Rad pokreće istraživanja na obuhvatnoj osnovi procesa uvodenja $i$ praktične implementacije Medunarodnih računovodstvenih standarda i Medunarodnih standarda finansijskog izvestavanja (MRS/MSFI) u Libiji odnosno u kompanijama koje su primarno istaknute na listingu nacionalne berze kapitala. Vrednuju se i procenjuju stanje, trendovi i reforme postojećeg nacionalnog obračunskog sistema, sa ciljem unapredenja najboljih korporativnih praksi u procesu obelodanjivanja finansijskih informacija iz finansijskih izvestaja korporacija, sto je pouratno korisna informcija i usmerenje za libijsku vladu i regulatorna tela u procesu nužnih i nezaobilaznih reformi obračunskog sistema kroz njegovu potpunu tranziciju na system MRS/MSFI.
\end{abstract}

Ključne reči: revizija / finansijsko izveštavanje / standardi izveštavanja

\section{REFERENCES}

1. Accountancy Age (2004). Why is the City in a Panic over IFRS?, Accountancy Age.

2. Almabrouk, M. (2005). The International Accounting and Its reflects on Arab Countries (Itrac, Benghazi). 
3. Bait EI-Mall, M., Smith, C. H., Taylor, M. (1973). The development of accounting in Libya. International journal of accounting, education and research, 8 (2), 83-101.

4. Cairns, D. (2004). The implications of IAS/IFRS for UK companies, International Journal of Disclosure and Governance, 1 (2), 107-118.

5. El-Sherief, Y. (1978). An empyrical investigation of Libya professional accounting services, an Unpublished PhD Thesis, University of Missouri.

6. Fearnley, S., Gillies, A., Hines, T., Willett, C. (2007). Bewildered but better informed: A qualitative interview based study into the attitudes of some UK accountants and regulators to the EU IFRS conversion project prior to its implementation in the UK, London, ICAEW

7. International Accounting Standards Committee (1989). Framework for the Preparation and Presentation of Financial Statements, London: IASC.

8. Kasanen, E., Kinnunen, J., Niskanen, J. (1992). The Prediction of International Accounting Standards Profits from Financial Statements of Finnish Firms, Advances in International Accounting, Vol. 5

9. Kilani, K. A. (1988). The evolution and status of accounting in Libya. An Unpublished $\mathrm{PhD}$ Thesis, University of Hull.

10. KPMG Ireland (2003). Financial Reporting Bulletin Supplement, November /December, Dublin, KPMG Ireland.

11. Larson, R. K., Street, D. L. (2004). Convergence with IFRS in an Expanding Europe: Progress and Obstacles Identified by Large Accounting Firms' Survey, Journal of International Accounting, Auditing and Taxation, Vol. 13

12. Lee, T., Tweedie, D. (1979). The Private Shareholder and the Corporate Report, London: Institute of Chartered Accountants in England and Wales.

13. Ortiz, E. (2005). GAAP Choice by European Companies, European Business Review, Vol. 17

14. Pierce, A., Weetman, P. (2000). Measuring financial reporting harmony and harmonisation: Perception versus reality, in: The Irish Accounting Review. Vol. 7, No. 2, 91-124.

15. Price Waterhouse Coopers (2004). World Watch: Governance and Corporate Reporting, Issue 1, London, PWC.

16. Teodori, C., Veneziani, M. (2005). The Impact of the IAS 38 on Financial Performances: A Survey of the Italian New Market, Paper presented at the European Accounting Association Congress, Gothenburg. 